\title{
Premiere Educandum
}

\section{Jurnal Pendidikan Dasar dan Pembelajaran}

\section{PE}

Premiere Educandum 7(2) 104 - 114 | Desember 2017

Copyright @2017 Universitas PGRI Madiun

ISSN: 2088-5350 (Print) / 2528-5173 (Online)

Available at: http://e-journal.unipma.ac.id/index.php/PE

DOI: $10.25273 /$ pe.v7i2.1596

\section{Efektivitas Model Pembelajaran Clis Berbantuan Media Slide Powerpoint Terhadap Hasil Belajar IPA}

\author{
Riska Fajar Ayu Kusuma Wardani ${ }^{1)}$, Moh. Rifai ${ }^{2)}$, Titin Kuntum Mandalawati ${ }^{3)}$ \\ ${ }^{1}$ Fakultas Keguruan dan Ilmu Pendidikan, Universitas PGRI Madiun \\ riskafajarayu@gmail.com \\ ${ }^{2}$ Pascasarjana PIPS, Universitas PGRI Madiun \\ muhamadrifaimpdi@yahoo.co.id \\ ${ }^{3}$ Fakultas Keguruan dan Ilmu Pendidikan, Universitas PGRI Madiun \\ mandalawatititin@yahoo.com
}

\begin{abstract}
This study based on fact that students of fifth grade in Pulerejo Elementary School rarely doing experiment so their natural science learning result was low. This study aims to determine the effectiveness of CLIS teaching model with slide powerpoint media on learning result of natural science in grade $\mathrm{V}$ student of Pulerejo elementary school. This research was kuantitatif with Quasy Eksperimental Design method and posttest only control design. This population research were all student of fifth grade in Pulerejo Elementary School with 22 sample students as experiment class and 20 sample studenst as control class. Sample were taken by simple random sampling with lotre technique. Data collected technique using test and documentation. The analyzed data using statistic method t-test with 5\% significant levels and $\mathrm{dk}=40$. The result showed that $t_{\text {obs }}$ bigger than $t_{\text {table }}=2,340>1,68385$ so $\mathrm{H}_{0}$ rejected and $\mathrm{H}_{1}$ accepted and the average value of posttest from experiment class was 82,36 , bigger than control class 74,20 . It can be concluded that there was effectiveness of CLIS teaching model with slide powerpoint media on learning result of natural science in grade V student of Pulerejo elementary school Pilangkenceng subdistrict Madiun in 2016/2017 academic year.
\end{abstract}

Keywords : CLIS, Slide Powerpoint, Natural Science Learning Result

\section{Abstrak}

Penelitian ini didasari fakta bahwa siswa kelas V SDN Pulerejo jarang melakukan percobaan sehingga hasil belajar IPA rendah. Penelitian ini bertujuan untuk mengetahui efektivitas model pembelajaran CLIS berbantuan media slide powerpoint terhadap hasil belajar IPA siswa kelas V SDN Pulerejo. Jenis penelitian ini adalah kuantitatif dengan metode Quasy Eksperimental Design dan desain penelitian posttest only control design. Populasi penelitian adalah siswa kelas V SDN Pulerejo dengan sampel 22 siswa sebagai kelas eksperimen dan 20 siswa sebagai kelas kontrol. Sampel ditentukan menggunakan simple random sampling dengan teknik lotre. Teknik pengumpulan data menggunakan tes dan dokumentasi. Analisis data menggunakan metode statistik rumus uji-t dengan taraf signifikan 5\% dan $\mathrm{dk}=40$. Hasil penelitian menunjukkan nilai $t_{\text {hitung }}$ lebih besar dari $t_{\text {tabel }}=2,340>1,68385$ sehingga $\mathrm{H}_{0}$ ditolak dan $\mathrm{H}_{1}$ diterima dan nilai rata-rata posttest kelas eksperimen 82,36 lebih besar dari kelas kontrol 74,20. Dapat disimpulkan bahwa ada efektivitas model pembelajaran CLIS berbantuan media slide powerpoint terhadap hasil belajar IPA siswa kelas V SDN Pulerejo Kecamatan Pilangkenceng Kabupaten Madiun Tahun Pelajaran 2016/2017.

Kata Kunci: CLIS, Slide Powerpoint, Hasil Belajar IPA

\section{A. PENDAHULUAN}

Salah satu mata pelajaran untuk meningkatkan kemampuan berfikir rasional adalah Ilmu Pengetahuan Alam. "Pada hakikatnya IPA dibangun atas dasar produk ilmiah, proses ilmiah, dan sikap 
ilmiah" (Trianto, 2014). Marlina (2016) menyatakan "IPA berkaitan dengan cara mencari tahu tentang fenomena alam secara sistematis, sehingga IPA bukan hanya penguasaan kumpulan pengetahuan yang berupa fakta-fakta, konsep-konsep atau prinsip-prinsip saja tetapi juga merupakan suatu proses penemuan". Jadi, IPA seharusnya mampu memfasilitasi peserta didik untuk mengalami proses belajar yang bermakna.

Kriteria tercapainya tujuan pembelajaran IPA dapat dilihat dari hasil belajar setelah mengalami proses pembelajaran. Susanto (2013) menjelaskan bahwa hasil belajar adalah kemampuan yang diperoleh siswa setelah melalui kegiatan belajar berupa perubahan perilaku yang relatif menetap dimana dapat diketahui melalui evaluasi kemudian dinyatakan dalam skor yang diperoleh dari hasil tes mengenai sejumlah materi pelajaran tertentu. Pendidikan IPA di Indonesia belum mencapai standar yang diinginkan. Padahal untuk memajukan IPTEK, sains penting dan menjadi tolak ukur kemajuan bangsa.

Hasil survey TIMSS (Trends in Mathematics and Science Study) tahun 2011, menunjukkan bahwa Indonesia berada di urutan ke-40 dari 42 negara di bidang sains. Sedangkan pada survey yang dilakukan oleh Programme for International Student Assesmen (PISA) tahun 2015, Indonesia menempati peringkat ke-69 dari 76 negara di bidang science. Penurunan hasil belajar siswa SD/MI terlihat dari Daftar Kolektif Hasil Ujian Sekolah (DKHUS) SD/MI 2016 yang dibagikan oleh Dinas Pendidikan (Dindik) Jatim kepada Dinas Pendidikan (Dispendik) Kabupaten/Kota, dari tiga matapelajaran yang diujikan pada US yakni Bahasa Indonesia, Matematika dan
Ilmu Pengetahuan Alam, secara nasional Jawa Timur mendapat nilai rata-rata 72,68. Untuk mapel IPA, siswa dengan nilai tertinggi $9,01-10,00$ hanya $51 \%$ dari total peserta US SD/MI se Jawa Timur. Kabupaten Madiun sendiri menempati urutan ke 5 dari seluruh Kabupaten/Kota di Jawa Timur.

Hal ini didukung fakta berdasarkan observasi awal pada kelas V SDN Pulerejo, pembelajaran IPA yang berlangsung hanya berfokus pada pengembangan Minds-on dan mengesampingkan pengembangan Handson siswa. Konsep pembelajaran seperti itu tampaknya tidak relevan lagi dengan tuntutan dan tantangan pendidikan saat ini. Hal ini membuat siswa menunjukan sikap kurang termotivasi dalam belajar karena pembelajaran tidak menarik sehingga berdampak pada hasil belajarnya. Hal lain disebabkan karena guru jarang memakai media pembelajaran yang dapat memvisualisasikan konsep IPA yang abstrak.

Siswa melakukan kegiatan eksperimen di kelas hanya 2 kali dalam 1 semester. Idealnya kegiatan eksperimen dilakukan pada setiap KD disesuaikan dengan karakteristik materi pembelajaran. Hal ini didukung dengan fakta terdapat $50 \%$ dari siswa kelas $\mathrm{V}$ memperoleh nilai di bawah KKM yang ditetapkan yaitu 65 pada Ulangan Harian IPA di semester II.

Maka dari itu, perlu ditawarkan konsep pembelajaran yang efektif yaitu adanya pembalikan makna belajar, berpusat pada siswa dan belajar dengan mengalami. Salah satu alternatif agar pembelajaran dapat berlangsung secara efektif adalah menggunakan model pembelajaran CLIS berbantuan media slide powerpoint. Tina dalam Joko (2013) menyatakan "Model CLIS (Children 
Learning In Science) merupakan model pembelajaran yang berusaha mengembangkan ide atau gagasan siswa tentang suatu masalah tertentu dalam pembelajaran serta merekontruksi ide atau gagasan berdasarkan hasil pengamatan atau percobaan". Ismail (2015) menyatakan "Model pembelajaran CLIS adalah kerangka berpikir untuk menciptakan lingkungan yang memungkinkan terjadinya kegiatan belajar mengajar yang melibatkan siswa dalam kegiatan pengamatan dan percobaan dengan menggunakan LKS".

Jadi, model pembelajaran CLIS adalah sebuah model pembelajaran yang mengutamakan kreatifitas siswa dan memberikan kesempatan kepada siswa untuk mengungkapkan ide atau gagasan yang dimilikinya secara menyeluruh, dan dapat mengembangkan gagasannya melalui percobaan sedangkan guru hanya sebagai fasilitator dan sebagai pembimbing. Peneliti memilih model CLIS karena memiliki beberapa kelebihan yaitu dapat membiasakan siswa untuk belajar mandiri dalam memecahkan suatu permasalahan yang ada, menciptakan pembelajaran yang lebih bermakna karena siswa terlibat langsung dengan melakukan sehingga timbul kebanggaan sendiri akibat menemukan sendiri konsep yang dipelajari, serta guru mengajar akan lebih efektif karena menciptakan pembelajaran yang lebih menyenangkan.

Menurut Sutarno (2009), langkahlangkah pembelajaran CLIS adalah sebagai berikut: 1) orientasi atau orientation; 2) pemunculan gagasan atau elicitation of ideas; 3) penyusunan ulang gagasan atau restructuring of ideas yang terbagi menjadi 3 tahap yaitu: a) pengungkapan atau pertukaran gagasan atau clarification and exchange; b) pembukaan pada situasi konflik atau exposure to conflict situation; c) kontruksi gagasan baru dan evaluasi atau construction of new ideas and evaluation; 4) penerapan gagasan atau application of ideas; 5) pemantapan gagasan atau review change in ideas.

Di SDN Pulerejo guru menggunakan media papan tulis dan gambar sederhana. Padahal di sekolah tersebut memiliki sarana LCD Projector yang jarang dimanfaatkan. Salah satu media yang dapat digunakan adalah melalui slide powerpoint. Powerpoint adalah program aplikasi di bawah microsoft office yang penggunaannya memerlukan bantuan LCD projector. Noprianti dan Syarifuddin (2015) menyampaikan "media slide powerpoint merupakan media perangkat lunak pengelola presentasi, objek, teks, grafik, video, suara, dan objek-objek lainnya yang dimasukkan dalam beberapa halaman yang efektif, profesional dan juga mudah".

Jadi, slide powerpoint merupakan salah satu perangkat lunak pengelola presentasi yang populer dari Microsoft Office dan berguna untuk menjelaskan materi yang disajikan ke dalam beberapa slide (layar) yang menarik dengan bantuan LCD Projector. Powerpoint memiliki kelebihan yaitu menarik, merangsang siswa, tampilan visual mudah dipahami, memudahkan guru, bersifat kondisional, dan praktis.

Penelitian mengenai model pembelajaran CLIS pernah dilakukan oleh Budiarti (2014) berjudul "Pengaruh Model Pembelajaran CLIS Terhadap Hasil Belajar IPA Siswa Kelas IV SD di Gugus III Kecamatan Busungbiu”. Hasil penelitiannya menunjukkan ada perbedaan yang signifikan pada hasil belajar IPA 
antara kelompok siswa yang dibelajarkan dengan model pembelajaran CLIS dan kelompok siswa yang dibelajarkan dengan model pembelajaran konvensional. Relevansinya dengan penelitian ini adalah sama-sama meneliti tentang model pembelajaran Children Learning In Science (CLIS).

Hal ini didukung pula oleh penelitian Prasetyaningsih (2016) yang berjudul "Pengaruh Penggunaan Media Pembelajaran dan Motivasi Terhadap Hasil Belajar IPA Kelas 3 SDN Doho Kecamatan Dolopo Tahun Pelajaran 2015/2016”. Hasil penelitian menunjukkan penerapan media pembelajaran powerpoint lebih baik daripada penerapan media pembelajaran poster terhadap hasil belajar IPA. Relevansinya dengan penelitian ini adalah sama-sama meneliti tentang media pembelajaran Powerpoint.

Berdasarkan uraian di atas, maka peneliti tertarik untuk melakukan penelitian tentang efektivitas model pembelajaran CLIS berbantuan media slide powerpoint terhadap hasil belajar IPA siswa kelas V SDN Pulerejo Kecamatan Pilangkenceng Kabupaten Madiun tahun pelajaran 2016/2017 dengan pokok bahasan sifat-sifat cahaya kelas V SD semester II. Melalui penelitian ini diharapkan dapat membantu siswa agar memperoleh hasil belajar yang lebih baik dan menentukan keberhasilan proses pembelajaran IPA.

\section{B. METODE PENELITIAN}

Metode penelitian yang digunakan adalah kuantitatif dalam bentuk metode eksperimen semu (Quasy Experimental Design). Menurut Sugiyono (2015) quasy experimental design merupakan desain penelitian yang mempunyai kelompok kontrol tetapi tidak dapat berfungsi sepenuhnya untuk mengontrol variabelvariabel luar yag mempengaruhi pelaksanaan eksperimen.

Variabel bebas (X) dalam penelitian ini adalah model pembelajaran CLIS berbantuan media slide powerpoint. Sedangkan variabel terikat (Y) dalam penelitian ini adalah hasil belajar IPA siswa kelas V SDN Pulerejo Kecamatan Pilangkenceng Kabupaten Madiun tahun pelajaran 2016/2017. Penelitian dibatasi pada hasil belajar ranah kognitif.

Desain penelitian yang digunakan dalam penelitian ini adalah Posttest-Only Control Design. Desain penelitian ini dilaksanakan pada dua kelompok, kelompok I tidak mendapatkan perlakuan penggunaan model pembelajaran CLIS berbantuan media slide powerpoint, dan kelompok II mendapatkan perlakukan menggunakan model pembelajaran CLIS berbantuan media slide powerpoint. Lalu keduanya diukur dengan diberi post-test. Penelitian ini digunakan untuk mengetahui perbedaan hasil belajar IPA akibat perlakukan yang diberikan pada siswa kelas V SDN Pulerejo. Desain penelitian yang digunakan dapat dilihat seperti gambar di bawah ini:

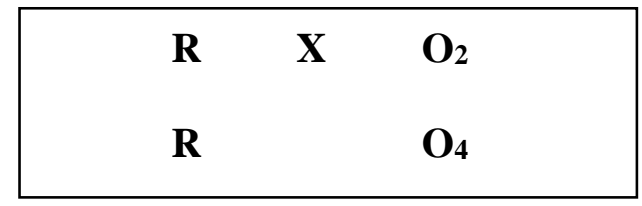

Gambar 1. Desain Penelitian

Keterangan:

$\mathrm{R}=$ Random

$\mathrm{O}_{2}=$ Kelompok Eksperimen yang diberikan Posttest

$\mathrm{O}_{4}=$ Kelompok Kontrol yang diberikan Posttest

$\mathrm{X}=$ Perlakuan

Populasi yang digunakan dalam penelitian ini adalah seluruh siswa kelas V 
dari 3 kelas di SDN Pulerejo yang berjumlah 62 siswa. Tiga kelas di sekolah tersebut setara secara akademik sehingga tidak terdapat kelas unggulan. Sampel untuk penelitian dipilih 42 siswa kelas V SDN Pulerejo, yang terdiri dari 22 siswa kelas $\mathrm{V}$ sebagai kelas eksperimen yaitu SDN Pulerejo 01 dan 20 siswa kelas V sebagai kelas kontrol yaitu SDN Pulerejo 02. Dalam melakukan pemilihan sampel penelitian, tidak dapat dilakukan pengacakan individu artinya tidak memungkinkan mengubah kelas yang terbentuk sebelumnya karena kelas V yang dijadikan sampel berapa di sekolah yang berbeda. Pengambilan sampel pada penelitian ini dilakukan dengan teknik simple random sampling, yang dirandom adalah kelas. Cara menentukan sampel dalam penelitian ini adalah dari seluruh populasi diundi untuk mendapatkan dua kelas dengan teknik lotre. Setelah diundi, terpilih kelas V SDN Pulerejo 01 sebagai kelas eksperimen dan kelas V SDN Pulerejo 02 sebagai kelas kontrol.

Teknik pengumpulan data yang digunakan dalam penelitian ini adalah 1) Tes berbentuk 35 soal pilihan ganda dalam bentuk posttest. 2) Dokumentasi berupa dokumen nama siswa kelas V SDN Pulerejo 01, SDN Pulerejo 02 dan SDN Pulerejo 03 dan nilai evaluasi hasil belajar IPA siswa kelas V SDN Pulerejo 01 dan Pulerejo 02 tahun pelajaran 2016/2017. Selain itu peneliti melengkapi data penelitian dengan foto, surat izin penelitian dll., untuk membuktikan bahwa penelitian ini benar-benar dilaksanakan oleh peneliti. Dokumentasi dilakukan untuk menentukan bentuk silabus, rpp, soal, dan materi pelajaran yang relevan yang akan digunakan dalam proses pembelajaran.
Sebagai langkah awal peneliti melakukan observasi awal dan menyusun proposal penelitian lalu melakukan uji coba sampai pemberian perlakuan dan pada tahap akhir dilakukan posttest pada kelas eksperimen dan kontrol, menganalisis hasil penelitian dan menyusun laporan penelitian. Langkah penyusunan instrumen tes adalah menjabarkan kisi-kisi soal berdasarkan indikator termasuk menyusun kunci jawaban, menentukan teknik penilaian dimana jawaban benar bernilai 1 dan jawaban salah bernilai 0 serta melakukan uji kelayakan tes hasil belajar melalui: 1) Uji validitas untuk mengetahui instrumen valid atau tidak menggunakan korelasi product moment dengan taraf signifikan $5 \%$ dan nilai $r_{\text {tabel }}=0,444$. Apabila soal tidak valid maka soal tidak dipakai. 2) Uji reliabilitas untuk mengukur ketetapan hasil tes. Jumlah butir pertanyaan adalah ganjil sehingga untuk menghitung tingkat reliabilitas tes digunakan rumus K-R 20. Apabila soal tidak reliabel maka soal tidak dipakai. 3) Derajad kesukaran untuk mengetahui apakah soal tergolong sukar, sedang atau mudah. 4) Daya beda untuk mengetahui apakah soal mampu membedakan siswa yang menjawab salah dan benar.

Analisis data dilakukan setelah seluruh data terkumpul. Pengujian hipotesis menggunakan uji-t. Sebelum melakukan analisis data, dilakukan uji prasyarat data terlebih dahulu yaitu uji normalitas dan uji homogenitas.

Uji Normalitas dilakukan terhadap data yang diambil untuk mengetahui apakah sampel berasal dari populasi yang terdistribusi normal. Uji normalitas menggunakan metode Lilliefors dengan taraf signifikansi $5 \%$ dan kriteria 
pengujian $\mathrm{H}_{0}$ diterima jika $\mathrm{L}_{\text {hitung }}<\mathrm{L}_{\text {tabel }}$ sedangkan $\mathrm{H}_{0}$ ditolak jika $\mathrm{L}_{\text {hitung }}>\mathrm{L}_{\text {tabel. }}$

Sedangkan uji homogenitas dilakukan untuk mengetahui apakah kelompok yang diteliti mempunyai varians yang sama. Uji homogenitas menggunakan uji $\mathrm{F}$ dengan dengan taraf signifikansi $5 \%, \mathrm{~F}_{\text {tabel }}$ dengan ketentuan $F_{\text {tabel }}\left(\alpha, \quad \mathrm{V} 1_{\mathrm{n}-1}, \quad \mathrm{~V} 2_{\mathrm{n}-1}\right), \quad$ dan kriteria pengujian jika $F_{\text {hitung }}>\mathrm{F}_{\text {tabel }}$ maka $\mathrm{H}_{0}$ ditolak dan $\mathrm{H}_{\mathrm{a}}$ diterima (harga varian tidak homogen). Jika $\mathrm{F}_{\text {hitung }}<\mathrm{F}_{\text {tabel }}$ maka $\mathrm{H}_{0}$ diterima $\mathrm{H}_{\mathrm{a}}$ ditolak (harga varian homogen).

Uji hipotesis menggunakan uji-t untuk membandingkan hasil belajar kelas eksperimen dan kelas kontrol Kriteria pengujian dengan taraf signifikansi 5\% dan derajad kebebasan $(\mathrm{dk})=n_{1}+n_{2}-2$, yaitu: jika $t_{\text {hitung }} \leq t_{\text {tabel, }}$ maka $\mathrm{H}_{0}$ diterima, jika $t_{\text {hitung }} \geq \mathrm{t}_{\text {tabel}}$, maka $\mathrm{H}_{0}$ ditolak.

\section{HASIL DAN PEMBAHASAN}

\section{Hasil Uji Kelayakan Instrumen Penelitian}

Jumlah item soal adalah 35 butir soal pilihan ganda yang diuji cobakan pada 20 siswa. Dengan taraf signifikansi $\alpha$ $=0,05$ diketahui $\mathrm{r}_{\text {tabel }}=0,444$. Hasil uji validitas adalah 25 soal yang valid dan 10 soal yang tidak valid. Dari hasil analisis uji reliabilitas yang dilakukan didapatkan hasil $r_{\text {hitung }}(0,866616533)>r_{\text {tabel }}(0,444)$, maka instrumen reliabel dan dapat digunakan untuk penelitian. Hasil uji tingkat kesukaran diperoleh 24 butir soal mudah dan 11 butir soal sedang. Kemudian hasil uji daya beda diperoleh hasil klasifikasi soal yang mempunyai daya beda tidak baik berjumlah 5 , klasifikasi soal yang mempunyai daya beda jelek berjumlah 2, klasifikasi soal yang mempunyai daya beda cukup berjumlah 12, dan klasifikasi soal yang mempunyai daya beda baik berjumlah 16 . Dari seluruh uji kelayakan butir soal diputuskan untuk menggunakan 25 butir soal pilihan ganda sebagai soal posttest untuk mengukur hasil belajar IPA.

\section{Hasil Pengolahan Data}

Dari hasil pengolahan data hasil belajar IPA kelas eksperimen diperoleh nilai rata-rata/mean $(\mathrm{M})=82,36$; nilai tengah $(\mathrm{Me})=80 ; \operatorname{modus}(\mathrm{Mo})=80$; standar deviasi $(\mathrm{SD})=9,535$. Nilai tertinggi 100 dan nilai terendah 68 . Seluruh siswa lulus KKM yang ditetapkan (65). Data dapat digambarkan melalui grafik berikut ini:

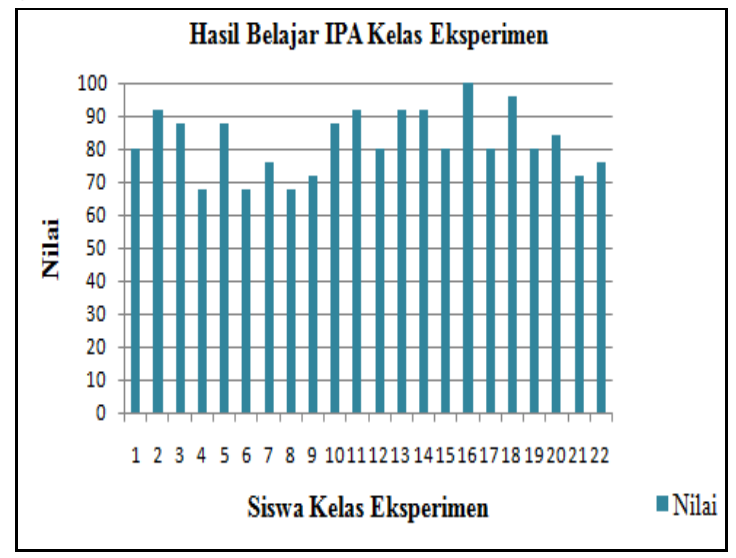

Gambar 2. Diagram Hasil Belajar IPA Kelas Eksperimen.

Skor tes yang diperoleh pada kelas kontrol memiliki rata-rata/mean $(\mathrm{M})=$ 74,20; median $(\mathrm{Me})=74$; $\operatorname{modus}(\mathrm{Mo})=$ 60 dan 92 ; standar deviasi $(\mathrm{SD})=13,008$. Nilai tertinggi 96 dan nilai terendah 56. Sebanyak 7 siswa berada di bawah KKM yang ditetapkan (65). Data digambarkan pada grafik berikut: 


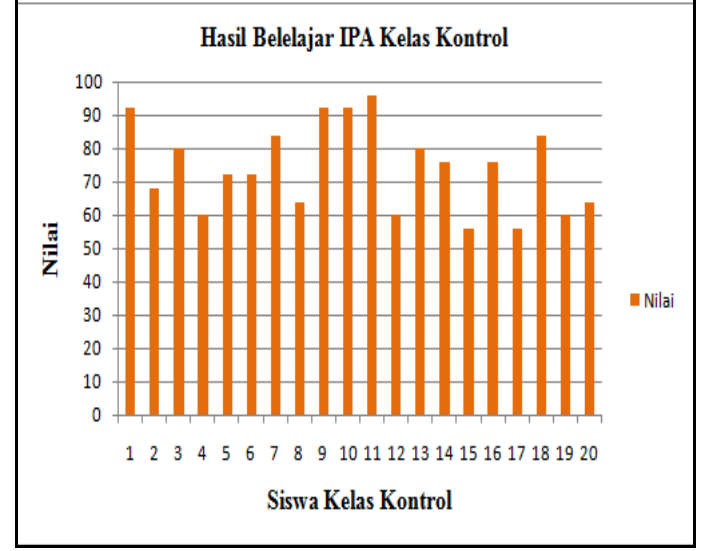

Gambar 3. Diagram Hasil Belajar IPA Kelas Kontrol.

Dari hasil tersebut dapat disimpulkan bahwa nilai posttest kelas eksperimen lebih unggul daripada nilai posttest kelas kontrol. Grafik perbandingan rata-rata nilai kelas eksperimen dan kelas kontrol digambarkan sebagai berikut:

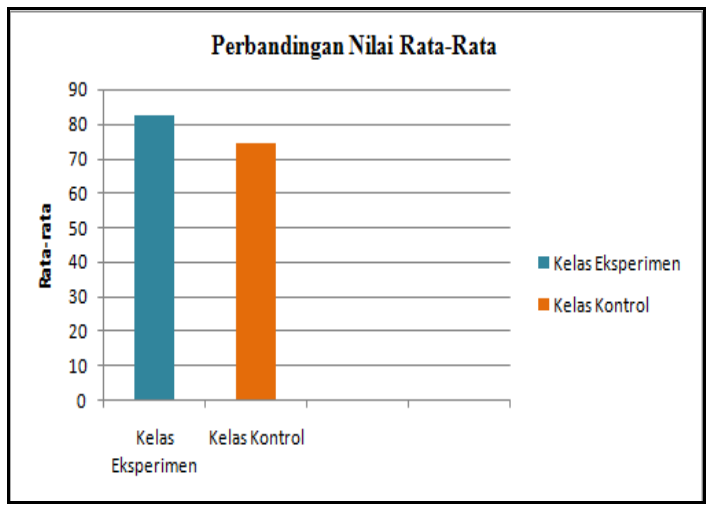

Gambar 4. Diagram Perbandingan Nilai Rata-rata Kelas Eksperimen dan Kelas Kontrol.

\section{Hasil Uji Prasyarat}

Dari analisis uji normalitas pada kelas eksperimen diketahui bahwa Lhitung $(0,1442)<\mathrm{L}_{\text {tabel }}(0,183)$ maka $\mathrm{H}_{0}$ diterima, sehingga data yang diperoeh berasal dari populasi yang berdistribusi normal. Sedangkan analisis uji normalitas pada kelas kontrol diketahui bahwa Lhitung $(0,1323)<\mathrm{L}_{\text {tabel }}(0,190)$ maka $\mathrm{H}_{0}$ diterima, sehingga data yang diperoleh berasal dari populasi yang berdistribusi normal.

Data di atas dihitung menggunakan uji $\mathrm{F}$ dan diperoleh hasil dari $\mathrm{F}_{\text {hitung }}=1,86$. Kemudian dibandingkan dengan $F_{\text {tabel }}$ guna mengetahui nilai homogenitas dari sampel. $F_{\text {tabel }}$ dapat dicari dengan $\alpha=0,05$ dan $\mathrm{dk}\left(\mathrm{n}_{1}-1 ; \mathrm{n}_{2}-1\right)$, maka diperoleh $\mathrm{F}_{\text {tabel }}=$ 2,11. Karena $F_{\text {hitung }}(1,86)<F_{\text {tabel }}(2,11)$, maka $\mathrm{H}_{0}$ diterima sehingga variansi populasi homogen.

\section{Hasil Uji Hipotesis}

Dari uji prasyarat diketahui bahwa data berasal dari populasi yang berdistribusi normal dan homogen sehingga dapat dilakukan uji hipotesis. Uji hipotesis menggunakan uji $t$ untuk mengetahui perbedaan hasil belajar IPA siswa kelas eksperimen dan kelas kontrol.

Dari hasil uji $t$ dengan taraf signifikansi $\alpha=0,05$ dan $\mathrm{dk}=40$ diketahui bahwa nilai $t_{\text {hitung }}=2,340$ dan $\mathrm{t}_{\text {tabel }}=1,68385$. Karena $\mathrm{t}_{\text {hitung }}(2,340)>$ $t_{\text {tabel }}(1,68385)$. Dapat disimpulkan bahwa $\mathrm{H}_{0}$ ditolak dan $\mathrm{H}_{1}$ diterima. Jadi keputusan uji hipotesis pada penelitian ini dinyatakan bahwa "Ada efektivitas model pembelajaran CLIS (Children Learning In Science) berbantuan media slide powerpoint terhadap hasil belajar IPA siswa kelas V SDN Pulerejo Kecamatan Pilangkenceng Kabupaten Madiun tahun pelajaran 2016/2017"

\section{Pembahasan}

Data yang diambil adalah nilai posttest siswa kelas V SDN Pulerejo materi cahaya dan sifatnya semester II. Pada kelas eksperimen, penelitian dilakukan dengan menggunakan model pembelajaran CLIS berbantuan media slide powerpoint. Siswa dibagi menjadi lima kelompok dimana setiap kelompok ditugaskan untuk mengkonstruksi pengetahuannya sendiri melalui kegiatan percobaan. Pada tahap orientasi peneliti membimbing siswa untuk menghubungkan pengetahuan awal siswa dengan pengetahuan baru yang akan dipelajari dengan mempertontonkan suatu 
fenomena yang sering terjadi dalam kehidupan sehari-hari melalui slide powerpoint .Kemudian memberikan soal uraian terbuka untuk mengeksplorasi pengetahuan awal siswa. Siswa berdiskusi dalam kelompoknya dan mengungkapkan gagasannya kepada seluruh siswa. Selanjutnya menyampaikan materi pada slide powerpoint.

Siswa diberikan kesempatan melakukan percobaan berdasakan LKK yang telah dibagikan dan berdiskusi dengan kelompoknya. Selanjutnya perwakilan kelompok mempresentasikan hasil diskusi di depan kelas. Pada akhir pembelajaran dilakukan posttest untuk melihat keberhasilan belajar siswa pada ranah kognitif. Diperoleh rata-rata hasil belajar siswa kelas eksperimen yaitu 82,36 .

Melalui langkah-langkah pembelajaran CLIS (Children Learning In Science) tersebut siswa terlihat sangat antusias. Hal ini dikarenakan siswa terlibat langsung dalam kegiatan pembelajaran. Akibatnya, siswa dapat membangun pengetahuannya secara sistematis dan terorganisir.

Kendala yang dialami peneliti selama proses penelitian pada kelas eksperimen adalah adanya antusiasme yang tinggi pada diri siswa pada saat melakukan kegiatan percobaan sehingga tidak jarang menimbulkan kegaduhan kecil di dalam setiap kelompok. Hal ini sangat wajar terjadi mengingat usia siswa sekolah dasar memasuki tahap operasional konkrit dimana mereka sangat tertarik belajar menggunakan benda-benda nyata dan memiliki rasa ingin tahu yang tinggi.

Masalah yang dihadapi tersebut dapat diatasi dengan menggunakan media slide powerpoint dimana pada slide tersebut telah tertera langkah percobaan yang harus dilakukan oleh siswa selain sudah tertera pada LKK. Di sisi lain, peneliti memberikan bantuan berupa penjelasan dalam melakukan kegiatan pembelajaran dan memberikan perhatian kepada siswa yang mulai gaduh saat pembelajaran.

Pembelajaran pada kelas kontrol tidak menggunakan model pembelajaran CLIS (Children Learning In Science) berbantuan media slide powerpoint. Siswa dibagi menjadi lima kelompok. Peneliti melakukan tanya jawab untuk mengetahui pengetahuan awal siswa kemudian menjelaskan materi cahaya dan sifatnya melalui ceramah berbantuan media gambar. Siswa diberikan Lembar Kerja Kelompok (LKK) kemudian berdiskusi dengan kelompoknya mengerjakan LKK. Setelah itu, siswa mempresentasikan hasil diskusinya kepada seluruh siswa di depan kelas.

Pada akhir pembelajaran dilakukan posttest untuk melihat keberhasilan belajar siswa pada ranah kognitif. Diperoleh ratarata hasil belajar siswa kelas kontrol yaitu 74,20. Rata-rata yang diperoleh lebih rendah dibandingkan kelas eksperimen. Siswa pasif karena konsep IPA disampaikan langsung oleh peneliti, jarang menggunakan media dan tidak melakukan percobaan. Siswa menjadi kurang memperoleh pemahaman yang mendalam terhadap konsep yang dipelajari.

Beberapa kendala yang dihadapi peneliti selama melakukan penelitian pada kelas kontrol diantaranya siswa mudah teralihkan perhatiannya oleh teman sebayanya ketika peneliti menjelaskan materi di depan kelas. Hal tersebut disebabkan karena siswa merasa jenuh saat pembelajaran berlangsung. Hanya beberapa anak saja yang mendominasi 
kegiatan diskusi sehingga peneliti harus berulang kali mengingatkan untuk bekerjasama dan memberikan umpanumpan pertanyaan agar siswa dapat terlibat aktif dalam diskusi. Peran peneliti sangat dominan dalam kegiatan pembelajaran sehingga membutuhkan waktu dan tenaga yang ekstra. Akibatnya, pekerjaan LKK beberapa kelompok tidak selesai tepat pada waktunya.

Berdasarkan nilai rata-rata hasil belajar IPA pada kelas eksperimen dan kelas kontrol, diketahui bahwa nilai ratarata IPA kelas eksperimen lebih tinggi daripada nilai rata-rata IPA dari kelas kontrol dengan selisih sebesar 8,16. Hal ini membuktikan bahwa penggunaan model pembelajaran CLIS (Children Learning In Science) berbantuan media slide powerpoint lebih efektif digunakan pada mata pelajaran IPA materi cahaya dan sifatnya terhadap hasil belajar . Hal tersebut disebabkan karena model pembelajaran CLIS (Children Learning In Science) memfasilitasi siswa melakukan percobaan untuk mengkonstruksi pengetahuannya sendiri sehingga siswa mengalami proses belajar yang bermakna sesuai dengan teori ausubel yang menyatakan bahwa belajar seharusnya merupakan asimilasi yang bermakna bagi siswa. Belajar bermakna merupakan suatu proses dikaitkannya informasi baru pada konsep-konsep relevan yang terdapat dalam struktur kognitif seseorang.

Hasil perhitungan nilai rata-rata tersebut dikuatkan dengan hasil uji hipotesis yang telah dilakukan yaitu diperoleh $t_{\text {hitung }}(2,340)>t_{\text {tabel }}(1,68385)$ dapat disimpulkan bahwa ada efektivitas model pembelajaran CLIS (Children Learning In Science) berbantuan media slide powerpoint terhadap hasil belajar IPA siswa kelas V SDN Pulerejo
Kecamatan Pilangkenceng Kabupaten Madiun tahun pelajaran 2016/2017.

Banyak faktor yang mempengaruhi hal tersebut diantaranya adalah karena model pembelajaran CLIS (Children Learning In Science) berbantuan media slide powerpoint ini termasuk model pembelajaran baru yang diterapkan di sekolah tersebut sehingga siswa antusias dalam pembelajaran. Selain itu, siswa di sekolah tersebut jarang melakukan kegiatan percobaan pada mata pelajaran IPA di sekolah. Oleh karena itu, dalam kegiatan pembelajaran siswa terlihat sangat senang dan fokus mengikuti tahap demi tahap percobaan. Melalui keterlibatan siswa secara langsung dalam kegiatan pembelajaran, kreativitas siswa dalam belajar menjadi terasah sehingga siswa aktif dalam pembelajaran.

Model pembelajaran CLIS (Children Learning In Science) memungkinkan siswa untuk saling berinteraksi dalam kelompok kecil yang heterogen. Sehingga siswa akan belajar bekerjasama. Pemahaman siswa terhadap materi tinggi karena siswa fokus dan sibuk terhadap kegiatan percobaan dan berdiskusi.

Penggunaan media pembelajaran slide powerpoint memiliki kelebihan yaitu dapat memfokuskan perhatian siswa karena penyajiannya menarik. Dengan permainan warna pada setiap slidenya, pemilihan huruf yang sesuai dan penggunaan animasi teks dan gambar yang menarik, perhatian siswa menjadi tertuju secara penuh terhadap materi. Karena siswa lebih fokus dan tertarik dalam pembelajaran, maka siswa akan lebih mudah memahami materi yang dipelajari. Hal ini dapat berpengaruh terhadap hasil belajar siswa yang baik. 
Pembelajaran yang efektif adalah pembelajaran yang mampu menciptakan suasana belajar yang menyenangkan sehingga tujuan belajar dapat tercapai. Dengan kriteria tersebut, maka pembelajaran dengan menggunakan model pembelajaran CLIS (Children Learning In Science) berbantuan media slide powerpoint adalah pembelajaran yang efektif. Karena dapat menciptakan suasana belajar yang menyenangkan, kegiatan pembelajaran tersebut juga mampu mencapai hasil belajar yang baik.

Hasil penelitian ini sejalan dengan penelitian yang telah dilakukan oleh Dewi (2014) yang berjudul "Pengaruh Model Children's Learning In Science Berbantuan Media Powerpoint Terhadap Hasil Belajar IPA Siswa Kelas V SD". Menurut Dewi, model pembelajaran Children's Learning In Science berbantuan media powerpoint dapat memberikan kesempatan pada siswa untuk menggali, menyusun dan mengkonstruksi pengetahuannya serta dapat menerapkan gagasannya tersebut. Media powerpoint dapat meningkatkan motivasi belajar siswa dan membuat siswa lebih tertarik mengikuti pembelajaran sehingga pembelajaran menjadi bermakna.

Pada akhirnya dapat ditarik kesimpulan dari penelitian ini yaitu ada efektivitas model pembelajaran CLIS (Childrean Learning In Science) berbantuan media slide powerpoint terhadap hasil belajar IPA siswa kelas V SDN Pulerejo Kecamatan Pilangkenceng Kabupaten Madiun tahun pelajaran 2016/2017.

\section{SIMPULAN}

Berdasarkan analisis yang telah dilakukan, dapat disimpulkan sebagai berikut: 1) Ada efektivitas model pembelajaran CLIS (Children Learning In Science) berbantuan media slide powerpoint terhadap hasil belajar IPA siswa kelas V SDN Pulerejo Kecamatan Pilangkenceng Kabupaten Madiun tahun pelajaran 2016/2017 materi cahaya dan sifatnya. Hal ini didukung dengan hasil $t_{\text {hitung }}(2,340)>t_{\text {tabel }}(1,68385)$, sehingga $\mathrm{H}_{0}$ ditolak dan $\mathrm{H}_{1}$ diterima. 2) Rata-rata nilai kognitif siswa kelas eksperimen $(82,36)$ lebih tinggi daripada kelas kontrol (74,20), menunjukkan pembelajaran menggunakan model pembelajaran CLIS berbantuan media slide powerpoint lebih efektif terhadap hasil belajar IPA. 3) Siswa yang belajar menggunakan model pembelajaran CLIS berbantuan media slide powerpoint lebih tertarik dan fokus mengikuti pembelajaran.

Peneliti lain yang hendak melakukan penelitian lebih lanjut dapat melengkapi kekurangan dari penelitian ini dengan ruang lingkup yang lebih luas agar lebih sempurna dan bermanfaat bagi dunia pendidikan pada umumnya.

\section{DAFTAR RUJUKAN}

Budiyarti, Luh Putu Yudha, Raga, Gede \& Sudhita, I Wayan Romi. (2014). Pengaruh Model Pembelajaran CLIS Terhadap Hasil Belajar IPA Siswa Kelas IV SD di Gugus III Kecamatan Busungbiu. Jurnal Mimbar PGSD Universitas Pendidikan Ganesha Jurusan PGSD, 2(1).

Dewi, P. Nym. T. T, Suadnyana, I Ngh \& Negera, I Gst. A. O. (2014). Pengaruh Model Children's Learning In Science Berbantuan Media Powerpoint Terhadap Hasil Belajar IPA Siswa Kelas V SD. Jurnal Mimbar PGSD Universitas Pendidikan Ganesha Jurusan PGSD, (2)1. 
Ismail, A. (2015). Penerapan Model Pembelajaran Children Learning In Science (CLIS) Berbantuan Multimedia Untuk Meningkatkan Penguasaan Konsep Fisika Siswa SMA. Petik. 1(1), 19-25.

Joko, T., Ahdinirwanto, R. W. \& Maftukhin, A. (2013). Peningkatan Kemampuan Berfikir Kritis Melalui Model Pembelajaran Children Learning In Science (CLIS) pada Siswa Kelas VIII SMP Negeri 1 Mirit Tahun Pelajaran 2012/2013. Radiasi. (3)2, 112-115.

Marlina, D. (2016). Pengaruh Konsep Diri dan Kedisiplinan Belajar Terhadap Penguasaan Konsep IPA. Premiere Educandum, 06 (01), 22-34.

Noprianti, I. D. \& Syarifuddin, A. (2015). Pengaruh Penerapan Media Slide Power Point Terhadap Hasil Belajar Siswa Kelas III Pada Mata Pelajaran IPA di Madrasah Ibtidaiyah Ahliyah 2 Palembang. Volume 1, 1-29.

Prasetyaningsih, T. (2016). Pengaruh Penggunaan Media Pembelajaran dan Motivasi Terhadap Hasil Belajar IPA Kelas 3 SDN Doho Kecamatan Dolopo Tahun Pelajaran 2015/2016. Skripsi tidak diterbitkan. Madiun: Program Studi Pendidikan Guru Sekolah Dasar.

Sugiyono. (2015). Metode Penelitian Kuantitatif Kualitatif dan $R \& D$. Bandung: Alfabeta.

Susanto, A. (2013). Teori Belajar \& Pembelajaran di Sekolah Dasar. Jakarta: Kencana Prenada Media Group.

Sutarno, N. (2009). Materi dan Pembelajaran IPA SD. Jakarta: Universitas Terbuka.

Trianto. (2014). Model Pembelajaran Terpadu Konsep, Strategi, dan Implementasinya dalam Kurikulum
Tingkat Satuan Pendidikan (KTSP). Jakarta: Bumi Aksara. 